\title{
Central Line-Associated Bloodstream Infections in Pediatric Intensive Care Unit
}

\author{
Çocuk Yoğun Bakım Ünitesinde Kateter Illişkili Kan Dolaşımı Enfeksiyonları
}

\author{
Tanıl Kendirli¹, Ayhan Yaman¹, Çağlar Ödek¹, Halil Özdemir², Adem Karbuz², Bilge Aldemir², Haluk Güriz³, Can Ateş4, Gamze Özsoy¹, \\ Derya Aysev33, Ergin Çiftçi², Erdal İnce ${ }^{1}$ \\ ${ }^{1}$ Ankara University Faculty of Medicine, Pediatric Intensive Care Unit, Ankara, Turkey \\ ${ }^{2}$ Ankara University Faculty of Medicine, Department of Pediatric Infectious Diseases, Ankara, Turkey \\ ${ }^{3}$ Ankara University Faculty of Medicine, Department of Microbiology Laboratory, Ankara, Turkey \\ ${ }^{4}$ Ankara University Faculty of Medicine, Department of Biostatistics, Ankara, Turkey
}

\section{Abstract}

Introduction: The aim of this study was to determine the frequency of central line-associated bloodstream infections, risk factors, their relationship with catheter insertion location, and the effect of central line-associated bloodstream infections on mortality and pediatric intensive care unit (PICU) length of stay.

Methods: This was a prospective, observational and cohort study, carried out between November 2009 and February 2011. During this period, all the patients who had central-line were monitored for central line-associated bloodstream infection.

Results: In the study period, 275 patients were admitted to our PICU. The frequency of invasive device usage was 38.9\% (107) for central venous catheter, $38.2 \%$ (105) for mechanical ventilation, $53.3 \%$ (147) for urinary catheter, and $11.3 \%$ (32) for artery line. Central lineassociated bloodstream infection was detected in $16(14.8 \%)$ of the patients and 23 central line-associated bloodstream infection attacks were observed. There were 14 central line-associated bloodstream infection attacks in 1.000 central venous catheter usage days. There were 168 patients without central venous catheter and 4 (2.4\%) of them had blood stream infection. Thirty-six patients died and the mortality rate was $13 \%$. Five of these patients (13.8\%) died due to central line-associated bloodstream infection, 27 (25\%) of them had central venous catheter and 9 (6\%) of them did not ( $p=0.001)$.

Conclusion: In conclusion, central line-associated bloodstream infection is one of the serious healthcare-associated infections, and it is an important cause of morbidity and mortality in PICUs.

Keywords: Nosocomial infection, central line-associated bloodstream infection, pediatric intensive care

\section{Öz}

Giriş: Bu çalışmanın amacı, kateter ilişkili kan dolaşımı enfeksiyonlarının sıklığını, risk faktörlerini, kateter yerleştirme yerleri ile olan ilişkisini, ayrıca bu enfeksiyonların mortalite ve çocuk yoğun bakım ünitesi (ÇYBÜ) kalış süresine olan etkisini belirlemektir.

Yöntemler: Kasım 2009 ve Şubat 2011 tarihleri arasında gerçekleştirilen ileriye yönelik ve gözlemsel bir kohort çalışmasıdır. Bu tarihler arasında, ünitemizde santral venöz kateteri olan tüm hastalar çalışmaya alındı.

Bulgular: Bu dönemde, çYBÜ'de 275 hasta izlendi. Invazif cihaz kullanım sıklığı; \%38,9 (107) santral venöz kateter, \%38,2 (105) mekanik ventilasyon, \%53,3 (147) idrar kateteri ve \%11,3 (32) arter kateteri idi. Hastaların 16'sında (\%14,8) (23 atak) kateter ilişkili kan dolaşımı enfeksiyonu saptandı. Bin santral venöz kateter kullanım gününde 14 enfeksiyon atağı gözlemlendi. Santral venöz kateteri olmayan 168 hastanın ise $4(\% 2,4)$ tanesinde kan dolaşımı enfeksiyonu saptandı. Hastaların 36'sı öldü, mortalite oranı \%13 idi. Bu hastalardan 5'i $(\% 13,8)$ kateter ilişkili kan dolaşımı enfeksiyonu nedeniyle öldü, 27'sinde (\%25) santral venöz kateter varken, 9'unda (\%6) yoktu $(p=0,001)$.

Sonuç: Kateter ilişkili kan dolaşımı enfeksiyonları, hastane ilişkili enfeksiyonlar içinde en ciddi olanlardan biridir ve çYBÜ'deki morbidite ve mortalitenin de önemli bir nedenidir.

Anahtar Kelimeler: Nozokomiyal enfeksiyon, kateter ilişkili kan dolaşımı enfeksiyonu, çocuk yoğun bakım

Address for Correspondence/Yazışma Adresi: Gamze Özsoy MD, Ankara University Faculty of Medicine, Pediatric Intensive Care Unit, Ankara, Turkey E-mail: gmzozsoy@gmail.com ORCID ID: orcid.org/0000-0001-6401-6069 Received/Geliş Tarihi: 29.05.2017 Accepted/Kabul Tarihi: 11.07.2017

${ }^{\circ}$ Copyright 2017 by Society of Pediatric Emergency and Intensive Care Medicine Journal of Pediatric Emergency and Pediatric Intensive Care published by Galenos Yayınevi. 


\section{Introduction}

Healthcare-associated infections (HAls) are hospital-acquired infections and preventable causes of morbidity and mortality in hospitalized patients. They are also associated with prolonged hospital stay. ${ }^{1-3}$ Some of the HAls are bloodstream infections (BSI) [frequently central line-associated bloodstream infection $(C L A B S I)$, nosocomial pneumonia [frequently ventilatorassociated pneumonia (VAP)], urinary tract infections [frequently catheter-associated urinary tract infection (CAUTI)], and surgical site infections. HAls surveillance plays a substantial role in hospital infection control and quality care. Therefore, surveillance studies are vital to understand how HAls affect the outcome of patients in pediatric intensive care units (PICUs). ${ }^{47}$

Most PICUs care for a heterogeneous population of children of varying age, diagnosis, and underlying illnesses. ${ }^{7,8}$ Critically ill children frequently require central lines [central venous catheter (CVC) and artery line). CVCs are used in PICU for various reasons such as inotropes, total parenteral nutrition, renal replacement therapies, plasma exchange, blood sampling, invasive monitoring, etc. 7,9,10

Despite the many benefits of CVCS in PICU, they carry significant risks such as CLABSI and thrombosis. CLABSI is one of the deadliest types of HAls, with a mortality rate of $12 \%-25 \% .{ }^{11-13}$ Several factors, such as those related to the patients (immunodeficiency, need for extracorporeal life support or renal replacement therapy), CVC use (prolonged catheterization, type of CVC material, and anatomical site of insertion and handling), have been shown to increase the risk of CVC infection. ${ }^{13}$

Here, we report an epidemiologic study about the CLABSIs in our PICU. The aim of this study was to determine the frequency of CLABSI, risk factors, the relationship of CLABSI with catheter insertion locations, and the effect of CLABSIs on mortality and PICU length of stay (LOS).

\section{Materials and Methods}

\section{Study Design}

This was a prospective and observational study held between November 2009 and February 2011. All patients involved in the study were monitored for the development of CLABSI from the day of PICU admission until 48 hours after PICU discharge. This study was performed at the PICU of the Children's Hospital in Ankara University Faculty of Medicine. Our PICU has 6 beds, and it is a level 3 PICU. There are 2 pediatric intensivists, 2 pediatric critical care medicine fellows, and nurse/patient rate is $1 / 2$ in daytime and $1 / 3$ in nighttime. We follow nearly 250 medical and surgical critically ill children, annually. Approval has been obtained from the Ankara University Ethics Committee.

\section{Data Collection}

A study form consisting of patient's demographic data, including age, gender, primary diagnosis, chronic diagnoses, and surgery knowledge, was employed. We calculated Pediatric Logistic Organ Dysfunction (PELOD) score ${ }^{14}$ at the admission and Pediatric Risk of Mortality III (PRISM III) score ${ }^{15}$ at $24^{\text {th }}$ hour of admission for all patients.

CVC were placed for multiple drug administration, inotropes usage, renal replacement therapies (hemodialysis and continuous venovenous hemodiafiltration), plasma exchange, etc. The location of CVC implantation (PICU or operation room) was recorded. At the time of this study, ultrasound was not employed during the CVC insertion. We have recorded the location of insertion such as vena jugularis interna, femoral vein, and subclavian vein. All CVCs were double-lumen in this study.

CVC days, and CLABSI attacks count in 1000 CVC days and the cause of CVC removal (unnecessary, CLABSI or obstruction) were recorded. Finally, the LOS, mortality and morbidity rate (with and without $C V C$ ) were determined. We use an infection preventive bundle for CLABSI in our unit.

\section{Definitions}

The Centers for Disease Control and Prevention (CDC) definitions were used to diagnose CLABSI. ${ }^{5}$ In our PICU, if the patient with CVC has fever, we concurrently take blood culture samples from all the catheter lumens, and peripheral vein. Samples are taken in equal amounts (1-3 mL). The tips of all removed CVC are taken for culture.

\section{Statistical Analysis}

The statistical analysis was performed with SPSS 15.0 (SPSS Inc. Chicago, IL). The differences in proportions between the group categories (patients with/without CVC, patients with/ without CLABSI) and CVC insertion locations were compared by chi-square test. Descriptive statistics were summarized in tables as counts and percentages for categorical variables and as mean \pm standard deviation. A p value of less than 0.05 was considered statistically significant. Additionally, we calculated the PICU LOS as well as survival to PICU discharge.

\section{Results}

The mean age of the patients was $87 \pm 87.4$ months. One hundred fifty-six (56.7\%) of them were girls. The mean PRISM III and PELOD scores were $7.6 \pm 9.9$ and $9.7 \pm 13.2$, respectively. The frequency of invasive device usage was $38.9 \%$ (107) for CVC, 38.2\% (105) for mechanical ventilation, 53.3\% (147) 
for urinary catheter and $11.3 \%$ (32) for artery lines. The insertion places of CVC were the operation room (mostly cardiac surgery) in $47(43.9 \%)$ of the patients, and PICU in 43 (40.2\%). Moreover; 17 patients had CVC (mostly Broviac catheter) at the admission to PICU. The locations of the CVC insertion were; internal jugular vein in 45 (48.9\%), femoral vein in $43(46.7 \%)$, and subclavian vein in $4(4.3 \%)$ of patients.

The total CVC usage days were 1589 in 107 patients with CVC, and the mean usage day was $14.7 \pm 9.7$ days. CLABSI was detected in 16 (14.8\%) patients (23 attacks). There were 14 CLABSI attacks in 1000 CVC usage days. CLABSI was developed at the $10.2 \pm 13.6^{\text {th }}$ day of the CVC insertion. The most frequent microbiological agent of CLABSI was Acinetobacter baumannii which was responsible from 6

Table 1. The microbiological agents of central line-associated blood stream infections

\begin{tabular}{|lll|}
\hline Microbiological agents & Patient number $(\mathrm{n})$ & $\%$ \\
\hline Acinetobacter baumannii & 6 & 25.8 \\
Coagulase-negative Staphylococci & 5 & 21.7 \\
ESBL $(+)$ Klebsiella pneumonia & 5 & 21.7 \\
VRE & 2 & 8.6 \\
Pseudomonas aeruginosa & 2 & 8.6 \\
Escherichia coli & 1 & 4.3 \\
Stenotrophomonas maltophilia & 1 & 4.3 \\
Candida parapsilosis & 1 & 4.3 \\
ESBL: Extended spectrum $\beta$-lactamase, VRE: Vancomycin-resistant enterococci \\
\hline
\end{tabular}

Table 2. The effect of blood stream infection to pediatric intensive care unit length of stay of patients with/without central venous catheter

\begin{tabular}{|c|c|c|c|}
\hline Group & $\begin{array}{l}\text { Number } \\
\text { of the } \\
\text { patients }\end{array}$ & $\begin{array}{l}\text { PICU length of stay (day) } \\
\text { median (min-max) (mean } \pm \text { SD) }\end{array}$ & $p^{*}$ \\
\hline CVC $(+)$ CLABSI (+) & 16 & $17.5(1-255)(43.7 \pm 63.7)$ & \multirow{2}{*}{0.005} \\
\hline CVC (+) CLABSI (-) & 91 & $7(1-71)(11.1 \pm 11.4)$ & \\
\hline CVC (-) BSI (+) & 4 & $41(3-51)(29.7 \pm 16.1)$ & \multirow[b]{2}{*}{0.001} \\
\hline CVC (-) BSI (-) & 164 & $3(1-37)(5.1 \pm 5.3)$ & \\
\hline \multicolumn{4}{|c|}{$\begin{array}{l}\text { PICU: Pediatric intensive care unit, CVC: Central venous catheter, CLABSI: Central } \\
\text { line-associated blood stream infection, BSI: Blood stream infection, SD: Standard } \\
\text { deviation } \\
\text { * } p \text { value is significant if less than } 0.05\end{array}$} \\
\hline
\end{tabular}

(25.8\%) of 23 infection attacks and the other agents are given on Table 1. There were 168 patients without CVC during the study period and $4(2.4 \%)$ of them had BSI. PICU-LOS in patients with/without CVC is given in Table 2 .

Thirty-six patients died and the mortality rate was $13 \%$. Five (13.8\%) of them died due to CLABSI. There was no statistical difference between insertion locations of CVC and mortality $(p=0.0642)$. The mortality rate was $25 \%$ and $6 \%$ in patients with and without $C V C$, respectively $(p=0.001)$.

\section{Discussion}

There are a few adult studies on nosocomial infections in intensive care units in Turkey ${ }^{16,17}$, but there is no study showing CLABSIs in PICU. This study is the first one evaluating the rate, risk factors, and outcomes of CLABSI in PICU patients in Turkey.

Our center is a member of the International Nosocomial Infection Control Consortium (INICC). ${ }^{18-22}$ Our hospital's INICC nosocomial infection rate and this rate's comparison with other INICC and CDC National Healthcare Safety Networks, covering the July 2010 - October 2012 period, are given in Table 3.

The risk of CLABSI increases exponentially day by day, especially after the first week of CVC placement. ${ }^{23}$ This emphasizes the importance of promptly removing unnecessary CVCs, particularly during the second week of catheterization and thereafter..$^{13,20,23}$ Niedner et al. ${ }^{13}$ reported that CLABSI incidence was 3.1/1000 central line-days in the PICUs in the USA between October 2006 and December 2007. They found that 99\% of patients with CLABSI were infection-free through day 7, but they demonstrated the daily risk of CLABSI doubled to $0.27 \%$ per day. Srinivasan et al. ${ }^{3}$ reported the data of CDC about CLABSI in all ICUs in the USA in 2001, 2008 and 2009. They reported that the CLABSI rate was 3.6 in 2001 and 1.65 in 2009 per 1.000 central-line days. Jackson et al. ${ }^{24}$ analyzed $85.849 \mathrm{ICU}$ patients and they detected CLABSI in 162 (0.2\%) of them. In our study, CLABSI developed especially after $7^{\text {th }}$ day of CVC insertion. It might be suggested that CVC may be changed in 7-10 day intervals, with the need for further studies.

Table 3. Our device-associated infections between July 2010 and October 2012, and the comparison of this rate and p values with International Nosocomial Infection Control Consortium and Centers for Disease Control and Prevention National Healthcare Safety Network

\begin{tabular}{|c|c|c|c|c|c|}
\hline DAl type & Our Infection rate* & INICC $(2004-2009)^{23}$ & $\begin{array}{l}\text { Our PICU vs INICC RR (CI 95\%) } \\
p\end{array}$ & CDC NHSN ${ }^{3}$ & $\begin{array}{l}\text { Our PICU vs CDC NHSN RR (CI 95\%) } \\
p\end{array}$ \\
\hline CLABSI & 13.3 & 10.7 & $1.25(0.77-2.02) 0.360$ & 3 & $4.51(2.79-7.29) 0.001$ \\
\hline VAP & 4.69 & 4.72 & $0.99(0.37-2.68) 0.990$ & 4.25 & $1.1(0.41-2.96) 0.844$ \\
\hline ITU & 6.46 & 6.46 & $1.59(0.92-2.75) 0.095$ & 1.84 & $5.58(3.2-9.71) 0.001$ \\
\hline
\end{tabular}


Cole et al. ${ }^{25}$ reported the prevalence of CLABSI in children whose stem cells were transplanted. They had found 5.3/1.000 central-line days and Staphylococcus epidermidis was the most commonly identified organism. In our study, Acinetobacter baumanni was the most frequent agent of CLABSI, and Staphylococcus epidermidis was the second one. Recently, multidrug resistant bacteria have been found to be the most common agent for all HAls forms such as CLABSI, VAP and CAUTI throughout the world. ${ }^{26-28}$

Some developing countries still have high HAls rate. The INICC recently reported that the pooled rate of CLABSI, 4.1 per 1.000 central line-days, was nearly 5 -fold higher than the 0.8 per 1.000 central line-days reported from comparable US ICUs. ${ }^{29}$ Dueñas et al. ${ }^{19}$ in their prospective cohort, active surveillance study in a PICU in El Salvador between January 2007 and November 2009 found that CLABSI incidence was 9.9/1.000 catheter-line days. Our data is comparable with Dueñas et al. ${ }^{19}$ data. It can be related with the insufficient places, nurse count, economic sources, and education in our countries.

Some clinicians think that femoral location of CVC has higher risk for CLABSI than the other sites. ${ }^{13,22,26}$ Krishnaiah et al..27 investigated the effect of the location of catheter insertion as external and internal CVC insertion. They determined that the rate of CLABSI was 23.1 and 9.7/1.000 catheterdays in patients with external and internal CVC, respectively. In our study, we have frequently used internal jugular and femoral vein as insertion site of CVC. There was not a significant difference between insertion sites and CLABSI rate. Additionally, we did not find a statistically significant difference between insertion places (PICU, operation room) and CLABSI rate. Besides that, the hospital acquired infection preventive bundles such as hand hygiene, insertion area sterilization, mask use, and sterile gown should be applied, even if the insertion place is PICU. ${ }^{27}$

\section{Conclusion}

In conclusion, CLABSI is a very important infection as an HAI. It can cause prolonged PICU stay as well as morbidity and mortality. Infection control committees must regularly inspect centers providing healthcare for critically ill children. Moreover, such centers must always try to improve their healthcare quality assuring hand hygiene adherence and isolation rules, and providing appropriate nurse to patient ratio, distance between patient beds, etc. Finally, PICU staff must apply the appropriate nosocomial infection preventive strategies.

\section{Ethics}

Ethics Committee Approval: Approval has been obtained from the Ankara University Ethics Committee.
Informed Consent: Approval was obtained from the family of the patients.

Peer-review: Internally peer-reviewed.

\section{Authorship Contributions}

Surgical and Medical Practices: T.K., A.Y., Ç.Ö., H.Ö., A.K., B.A., H.G., C.A., G.Ö., D.A., E.Ç., E.I., Concept: T.K., A.Y., Ç.Ö., H.Ö., A.K., B.A., H.G., C.A., G.Ö., D.A., E.Ç., E.I., Design: T.K., A.Y., Ç.Ö., H.Ö., A.K., B.A., H.G., C.A., G.Ö., D.A., E.Ç., E.I., Data Collection or Processing: T.K., A.Y., Ç.Ö., H.Ö., A.K., B.A., H.G., C.A., G.Ö., D.A., E.Ç., E.I., Analysis or Interpretation: T.K., A.Y., Ç.Ö., H.Ö., A.K., B.A., H.G., C.A., G.Ö., D.A., E.Ç., E.I., Literature Search: T.K., A.Y., Ç.Ö., H.Ö., A.K., B.A., H.G., C.A., G.Ö., D.A., E.Ç., E.I., Writing: T.K., A.Y., Ç.Ö., H.Ö., A.K., B.A., H.G., C.A., G.Ö., D.A., E.Ç., E.I.

Conflict of Interest: No conflict of interest was declared by the authors.

Financial Disclosure: The authors declared that this study received no financial support.

\section{References}

1. Wheeler DS, Giaccone MJ, Hutchinson $N$, Haygood $M$, Bondurant P. A hospital-wide quality-improvement collaborative to reduce catheter-associated bloodstream infections. Pediatrics. 2011;128:995-1004

2. Miller MR, Griswold M, Harris JM, Yenokyan G, Huskins WC, et al. Decreasing PICU catheter-associated bloodstream infections: NACHRI's quality transformation efforts. Pediatrics. 2010;125:20612.

3. Srinivasan $A$, Wise $M$, Bell $M$. Centers for Disease Control and Prevention (CDC). Vital signs: Central line-associated blood stream infections-United States, 2001, 2008, and 2009. MMWR Morb Mortal Wkly Rep. 2011;60:243-8.

4. Edwards JR, Peterson KD, Mu Y, Banerjee S, Allen-Bridson K, et al. National Healthcare Safety Network (NHSN) report: data summary for 2006 through 2008, issued December 2009. Am J Infect Control. 2009;37:783-805.

5. Huskins WC. Quality improvement interventions to prevent healthcare-associated infections in neonates and children. Curr Opin Pediatr. 2012;24:103-12.

6. Advani S, Reich NG, Sengupta A, Gosey L, Milstone AM. Central line-associated bloodstream infection in hospitalized children with peripherally inserted central venous catheters: extending risk analyses outside the intensive care unit. Clin Infect Dis. 2011;52:1108-15.

7. Odetola FO, Moler FW, Dechert RE, VanDerElzen K, Chenoweth C. Nosocomial catheter-related bloodstream infections in a pediatric intensive care unit: risk and rates associated with various intravascular technologies. Pediatr Crit Care Med. 2003;4:432-6.

8. Urrea M, Pons $M$, Serra $M$, Latorre C, Palomeque A. Prospective incidence study of nosocomial infections in a pediatric intensive care unit. Pediatr Infect Dis J. 2003;22:490-3.

9. Yogaraj JS, Elward AM, Fraser VJ. Rate, risk factors and outcomes of nosocomial primary bloodstream infection in pediatric intensive care unit patients. Pediatrics. 2002;110:481-5. 
10. Tomlinson D, Mermel LA, Ethier MC, Matlow A, Gillmeister B, et al. Defining bloodstream infections related to central venous catheters in patients with cancer: a systematic review. Clin Infect Dis 2011;53:697-710.

11. Wagner M, Bonhoeffer J, Erb TO, Glanzmann R, Häcker FM, et al. Prospective study on central venous line associated bloodstream infections. Arch Dis Child. 2011;96:827-31.

12. Nowak JE, Brilli RJ, Lake MR, Sparling KW, Butcher J, et al. Reducing catheter-associated bloodstream infections in the pediatric intensive care unit: Business case for quality improvement. Pediatr Crit Care Med. 2010;11:579-87.

13. Niedner MF, Huskins WC, Colantuoni E, Muschelli J, Harris JM, et al. Epidemiology of central line-associated bloodstream infections in the pediatric intensive care unit. Infect Control Hosp Epidemiol. 2011; 32:1200-8.

14. Leteurtre S, Martinot A, Duhamel A, Proulx F, Grandbastien B, Cotting J, et al. Validation of the pediatric logistic organ dysfunction (PELOD) score: prospective, observational, multicenter study. Lancet. 362:192-7.

15. DiCarlo JV, Frankel LR. Scoring systems and predictors of mortality. In: Behrman RE, Kliegman RM, Jenson HB (eds). Nelson textbook of pediatrics 17th ed. Philadelphia, USA: Elseiver Saunder; 2004:2779.

16. Dogru A, Sargin F, Celik M, Sagiroglu AE, Goksel MM, et al. The rate of device-associated nosocomial infections in a medical surgical intensive care unit of a training and research hospital in Turkey: one-year outcomes. Jpn J Infect. 2010;63:95-8.

17. Ozdemir H, Kendirli T, Ergün H, Ciftçi E, Tapisiz A, et al. Nosocomial infections due to Acinetobacter baumannii in a pediatric intensive care unit in Turkey. Turk J Pediatr 2011;53:255-60.

18. Rasslan O, Seliem ZS, Ghazi IA, El Sabour MA, El Kholy AA, et al. Device-associated infection rates in adult and pediatric intensive care units of hospitals in Egypt. International Nosocomial Infection Control Consortium (INICC) findings. J Infect Public Health. 2012;5:394-402.

19. Dueñas L, Bran de Casares A, Rosenthal VD, Jesús Machuca L. Device-associated infection rates in pediatric and neonatal intensive care units in El Salvador: findings of the INICC. J Infect Dev Ctries. 2011;5:445-51.

20. Rosenthal VD, Ramachandran B, Villamil-Gómez W, Armas-Ruiz A, Navoa-Ng JA, et al. Impact of a multidimensional infection control strategy on central line-associated bloodstream infection rates in pediatric intensive care units of five developing countries: findings of the International Nosocomial Infection Control Consortium (INICC). Infection. 2012;40:415-23.
21. Navoa-Ng JA, Berba R, Galapia YA, Rosenthal VD, Villanueva VD, et al. Device-associated infection rates in adult, pediatric and neonatal intensive care units of hospital in the Philippines: International Nosocomial Infection Control Consortium (INICC) findings. Am J Infect Control. 2011;39:548-54.

22. Rosenthal VD, Bijie H, Maki DG, Mehta Y, Apisarnthanarak A, et al. International Nosocomial Infection Control Consortium (INICC) report, data summary of 36 countries, for 2004-2009. Am J Infect Control. 2012;40:396-407.

23. Ullman RF, Gurevich I, Schoch PE, Cunha BA. Colonization and bacterimia related to duration of triple-lumen intravascular catheter placement. Am J Infect Control. 1990;18:201-7.

24. Jackson SS, Leekha S, Magder LS, Pineles L, Anderson DJ, et al. The effect of adding comorbidities to current centers for disease control and prevention central-line-associated bloodstream infection riskadjustment methodology. Infect Control Hosp Epidemiol. 2017;3:16.

25. Cole TS, Rogerson E, Collins J, Galloway A, Clark J. Central venous catheter related blood stream infections in children undergoing hemotopoietic stem cell transplant for primary immunedefiency and other nonmalignant disorder. Pediatr Infect Dis J. 2011;30:1098100.

26. Peng S, Lu Y. Clinical epidemiology of central venous catheterrelated bloodstream infections in an intensive care unit in China. J Crit Care. 2013;28:277-83.

27. Krishnaiah A, Soothill J, Wade A, Mok QQ, Ramnarayan P. Central venous catheter-associated infections in a pediatric intensive care unit: Effect of the location of catheter insertion. Pediatr Crit Care Med. 2012;13:176-80.

28. Abramczyk ML, Carvalho WB, Medeiros EA. Preventing catheterassociated infections in the pediatric intensive care unit: Impact of an educational program surveying policies for insertion and care of central venous catheters in a Brazilian teaching hospital. Braz J Infect Dis. 2011;15:573-7.

29. Rosenthal VD, Al-Abdely HM, El-Kholy AA, AlKhawaja SA, Leblebicioglu $\mathrm{H}$, et al. International Nosocomial Infection Control Consortium report, data summary of 50 countries for 2010-2015: Device-associated module. Am J Infect Control. 2016;1;44:1495504. 